\title{
Digital Addiction in Indonesian Adolescent
}

\author{
Mutimmatul Faidah, Setya Chendra Wibawa, Rooselyna Ekawati \\ Universitas Negeri Surabaya \\ mutimmatulfaidah@unesa.ac.id
}

\begin{abstract}
A serious problem faced by the adolescent in the vast development of Information Technology era is a digital addiction. This descriptive study examines the types of digital addiction and the relation between digital addiction among adolescents and parenting approaches. Respondents in this study were adolescents between 11 and 13 years old amounted to 109 students who were recruited from junior high schools in Surabaya Indonesia. Respondents were randomly selected and all credentials are classified. Data collection was conducted through an assessment questionnaire using Young's Digital Addiction Test (YIAT). The data were analyzed by using descriptive methods. The results show that $27.2 \%$ of respondents are categorized as digital addicts. The types of addictive behavior are covered are cyber relationships, gaming, and even cybersex. According to this study, there is a significant relation between parenting approaches and digital addiction for the adolescent. Teenagers with positive parenting experience a lower prevalence of digital addiction than those with permissive parenting and authoritarian styles. Based on the results, we need socialization to use the internet intelligently and the formulation of a strategy for a Digital Addiction Recovery Program.
\end{abstract}

Keywords- addiction, the internet, teenager, parenting, behavior.

\section{INTRODUCTION}

The internet in the 21 st Century has changed various patterns of human behavior, from the social order, economy, education, to life styles. The Internet has become a glowing star that fascinates the whole world as it can make it difficult, bringing a far, simplifying and complicated one. Electronic devices such as Smart phones, tablets, and computers are now easily connected to the Internet, facilitating for social networking, gaming, searching, gambling, trading, shopping, and so forth. The digitization of all aspects is now inevitable fact. In the context of teenagers in Indonesia, almost every teenager has at least one Android Phone. Schools and parents lose control as the teenagers have mobile phones and become part of the digital world. However, the important thing is to prepare the teenagers to be smart in utilizing digital media.

Based on research by the Association of Internet Service Providers in Indonesia (AJPII), the number of internet users in Indonesia in 2016 reached 132.7 million people or $51.8 \%$ of the total population of Indonesia. The figure was ranked the sixth largest in the world after China, the U.S., India, Brazil, and Japan. Internet users aging 10-24 years old reached up to
$10.4 \%$; among these were students reaching up to $6.3 \%$ or equivalent to 8.3 million teenagers with penetration reached $69.8 \%$. The majority of internet users are teenagers living with the family (father and mother). This means parents and family have an important role in preventing Digital Addiction among the teenagers [1]

Adolescence is one of the most important developmental stages for human life. An adolescent is someone who is about to mature is puberty and is beginning to grow their love and lust as well. In general, experts divide adolescence into three stages, namely, early adolescence, (11-13 years); mid adolescence (14-17 years); and late adolescence (18-21 years). Puberty in the adolescent stage nowadays tend to experience early maturation [2]. Such phenomenon as adolescent growth spurts occur during this period. The growth of body weight shapes the body of a female child, into women, and boys, into men. Changes in physical body shape may cause adolescents to pay attention to the appearance of self [3].

Adolescents and the Internet are two things that cannot be separated. The intensity of the adolescents browsing the cyberspace has an impact such as internet addiction. Research on the Digital Addiction has been conducted in several countries. Hillarie Cash, Cosette D Rae, Ann H Steel, and Alexander Winkler, in their study "Digital Addiction: A Brief Summary of Research and Practice", show results that addiction to the internet is increasing rapidly. There are different views of the types of the addiction, including behavioral addiction, impulse control disorder, or even obsessive compulsive disorder due to the addiction. Types of Digital Addiction includes online sexual (cyber sex), online games, and even excessive internet surfing [4]. Digital addiction (AD) is becoming a crucial issue in the research field. In some countries, such as China and South Korea, DA causes health issues followed that should be followed by some actions such as prevention and treatment through education, therapy, and research [5].

Digital addiction is not only occurs in China, Korea, and America, but in Indonesia as well. This study will elaborate the activities of Indonesian teenagers surfing the Internet, the level of dependence or addiction of teenagers on the Internet, and the relationship of internet addiction with parenting approaches. Respondents were 109 early adolescents in 
Surabaya, Indonesia, who are in junior high school aging, 1214. Data collection was conducted through assessment questionnaire by using Young's Digital Addiction Test (YIAT).

\section{DIGITAL ADDICTION AMONG INDONESIAN ADOLESCENTS}

Digital addicts are those who interact in an intense and deep manner with technology. Online surfing activities control teenagers, thereby adversely affecting the well-being of the users. Digital Addiction (DA) is a label for someone whose daily activities are exposed to the digital devices, mainly mobile phones. This label is a warning and able to take positive steps to avoid digital addiction [6].

Digital addiction oriented to someone's physical and mental behavior; in addition to that, the addiction may occur on the use of digital devices. The debatable discourse is whether the digital device an addictive quality, such as a drug or just an exaggerated concern that has arisen. Based on research in December 2013 conducted by a team of researchers from the University of Maryland concluded that the majority of students' addictions to technological devices have similar symptoms when they are separated from addictive substances such as drugs.

There are four levels of digital addiction: excessive use (addiction that excessively uses the digital), withdrawal (the emotion easily ignited if it cannot access the Internet), tolerance (following and fulfilling the desire to have the IT device as per certain time), and negative repercussions (selfsocial performance, self-isolation, poor performance and indifference to the outside world due to the technology) [7].

To find out the categories of DA in adolescents, researchers have modified the Young's Digital Addiction Test (YIAT) questionnaire with the statements referring to the following psychical and behavioral conditions [8]: abandonment of chores and work duties for the sake of online surfing, preference to the Internet media as their close friend, gaining new friends while online surfing, complaints from others because they spend a lot of time online, frequently checking email before doing any urgent things, being disturbed by surfing online while learning/studying, insecure about what they do online, transferring life problems by online surfing, self-management ability for being online again, fear of living without the Internet, it will be boring, empty and unpleasant?, being angry if disturbed while online, sleepless due to Internet use late at night, placing time to get online while mingling with others, and following IT cutting edge products.

The data obtained through the research shows there are five main reasons that the teenagers access the Internet. The reasons are socializing, searching for daily information, having fun, finding materials for doing school work, filling free time, and being part of a lifestyle.

The main reason for accessing the Internet is dominated by the communication and social interaction in cyberspace. Activities that the adolescents do when accessing the Internet based on the research results are as follows: chatting and accessing social media, searching information and update knowledge, online gaming, accessing porn sites, downloading and uploading (films, music, and videos), online shopping, managing private blogs, and accessing email.

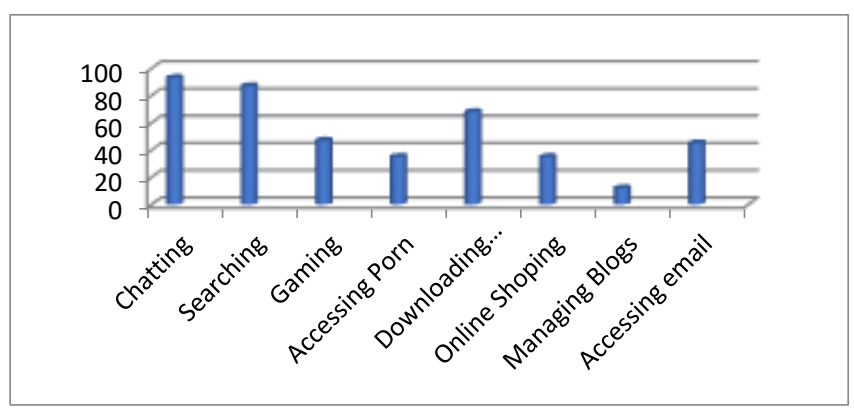

Figure 1: Types of Activities

Based on the data, it was known that the dominant activity while accessing the Internet is to maintain communication through social media networking. This activity is believed as the medium for the adolescence to search identity, particularly in the adolescent period. The desire to look for more friends and maintain friendly communication with peers even is more important than maintaining communication with their family members. Moreover, a teenager may have more than one social media accounts, namely: Face book, Line, What App, Instagram, messenger and more. This type of digital addiction through cyber-based interactions takes a very significant time during the adolescent. A teenager is willing to be in the room all day with only mobile phones and internet access. This affects the loss of time of interaction with the family members, and this may affect the real life destructively. In this context, Gandolfi released several types of digital addiction, namely: Face book Addiction Disorder (FAD), YouTube Addiction Disorder (YAD), Google Search Addiction Disorder (GSAD), Widget Addiction Disorder (WAD), Twitter Addiction Disorder (TAD), and Blackberry Addiction Disorder (BAD) [8].

The second most frequent activity while accessing online is to gain information, news, and knowledge to enhance their insights. Playing online game also made $45 \%$ of total respondents. Online activity to access pornography and sex sites was found at $35 \%$. On the other hand, online shopping has not become major lifestyle among teenagers and uploading, writing on personal blogs is also not much preferable among junior high school students. 
Those behaviors could be seen that Digital Addiction may cause a negative impact, especially for children and adolescents. The most common threat when a person is addicted to the Internet is their inability to manage their emotions. Someone will feel easily sad, lonely, angry, embarrassed, and being afraid of getting out of their circle. In addition, they feel they are in a situation of high family conflict and have low self-esteem. This situation may cause the children and adolescents to become introverted and indifferent to the surrounding environment, affecting their social life, such as relationships with peers or family. In addition to the environment, they may also become indifferent to the responsibilities of students who have an impact on their performance. If it persists, the Internet addicts may become someone who is antisocial and increase the risk of juvenile delinquency at the end.

\section{Digital AdDiction AND PARENTING APPROACHES}

Digital addiction experienced by $27 \%$ of the respondents of the four variants of digital addiction is caused by the communication intensity within the family and parental care system. Parenting is the whole interaction between parent and children in the family. In such interactions can be seen how to communicate, respect, pay attention, discipline and behave towards the children [9]. The family through the parent interaction takes the role in the formation of the children behavior and development of the adolescents. These interactions include attitude, characteristics, temperament, personality, education and other treatments. There are three categories of parenting of children:

\section{A. Authoritarian}

Parents give strict rules to their children; if the children fail to comply with the rules, they will receive severe punishment as the consequence. But if the children succeed in fulfilling what their parents expect, they will receive little appreciation or no appreciation at all [10]. The result of authoritarian parenting patterns is very dramatic, and this may result in the child of becoming aggressive or not responding to all activities in the surrounding environment because the children are less critical, lazy to do things to be faced and not excited [11]. In the context of this study, this authoritarian pattern is a form of children who are forbidden by the parents to have Android mobile phone or the implementation of strict rules of using the mobile phones at home.

\section{B. Permissive (liberal)}

This approach allows children to act in accordance with their desires, and they tend to act without control. Obligations and responsibilities are not demanded by the parents, but the children have the same rights as the parents. Parents especially mothers are indifferent in caring for their children [12]. Permissive parenting approach may result in the child becoming selfish. As said by Elizabeth B. Hurlock that "this parenting approach which the parents let their children do as they are pleased with little restraint. This creates a childcentered household [13]. In association with the use of the Internet among the adolescents, parents who implement such permissive parenting approach do not care about what the children are accessing on the Internet. Parents of this type feel calm and happy as long their children are at home every day and enjoy the days with silence in the room.

\section{Democratic}

The democratic way in parenting is the combination of authoritarian and permissive parenting approach as stated by Paul Hauck [14]. Children receive limited freedom, parents communicate with children about what is allowed and prohibited, create mutual understanding, and parents act as needed [15]. Democratic parenting can be said to be ideal because it prioritizes the approach that utilizes explanations, discussions, and reasoning to help the child understand why he is expected to act in a certain way. The implementation of these three types of parenting is in the range of light to extreme dimensions, although no parenting pattern is truly purely theoretical as applied above. Parents with this democratic type will make deals with the children related to time management for online surfing.

The adolescents experience significant biological, psychological, and social changes. Those who have problems in controlling their online activities are very vulnerable to the Digital Addiction. Parents, in this case, have important roles in protecting the prone teenagers on the Digital Addiction by intensifying appropriate communication and parenting patterns to their children. Based on the results of the study, it is known that family relations and positive interactions within the family play important roles in preventing the children from the Digital Addiction.

Among the 109 students who have used the Internet, 80 students $(72.8 \%)$ are regular Internet users, and $29(27.2 \%)$ are Internet addicts. Respondents consisted of 58 (53.2\%) female students and $51(46.8 \%)$ were males. For the students who experience the Digital Addiction, about $53 \%$ of students' parents are permissive of the behavior and development of the children, while the other $36 \%$ of the students' parenting system is authoritatively implemented, and about $11 \%$ of students are with democratic parenting approach.

The results of this study are consistent with the findings of Cynthia Sau Ting Wu, Ho Ting Wong, Kin Fai Yu, Ka Wing Fok, Sheung Man Yeung, Cheuk Ho Lam and Ka Man Liu who reviewed "Parenting approaches, family functionality, and Digital Addiction among Hong Kong adolescents". The results show that Digital Addiction is quite common among Chinese adolescents particularly in Hong Kong, and family-based prevention strategies should be tailored to risk factors resulted by the Digital Addiction. Digital addiction is even more common in adolescents from divorced families, low-income families, families where 
domestic conflicts exist and highly dysfunctional families [16].

Regarding the dangers of the addiction to the Internet addicts, it is important to anticipate through proper actions, especially among children and adolescents. Anticipation can be done with the discipline pattern and limitation of the time in using the gadgets or other digital devices. In this case, the need for supervision from parents among children accessing digital devices is imperative. In addition, children and adolescents need to get educated about the dangers of Digital Addiction, so they have an understanding and awareness that the desire of accessing the Internet needs to be controlled. Another effort is to provide a variety of alternative activities that may divert the teenagers from dependence on online activities with various real productive activities, such as sports, playing music, painting, and developing their potential.

\section{CONCLUSION}

This study concluded that parents have a significant role in preventing digital addiction among children. The types of Digital Addiction in teens may vary, starting from excessive use, withdrawal, tolerance, to negative repercussions. Adolescents with less democratic family background have less prevalence digital addiction than those with permissive and authoritarian parenting approach. Based on the results of this study, there should be parental involvement in preparing a strategic move to prevent digital addiction among adolescents. Anticipation should be done so that teenagers are dependent on the digital devices through education and socialization of the dangers of digital addiction as well as providing real alternatives productive activities according to potential and talent of the adolescents.

\section{REFERENCES}

[1] AJPII, "Info Graphic: Survey on Penetration and Behavior of Indonesian Internet Users in 2016," Kompas, Jakarta, 2016.

[2] S. Agus, Psikologi Perkembangan, Jakarta: Rineka Cipta, 2014.

[3] A. Purwakania, Psikologi Perkembangan Islami, Jakarta: Raja Grafindo Jakarta, 2016.

[4] C. D. R. A. H. S. A. W. Hilarie Cash, "Digital Addiction: A Brief Summary of Research and Practice," 2016

[5] R. Joseph, "Issue for DSM-V: Digital Addiction," Journal of Psychiatry , vol. 165, no. Psychiatry, p. 3, 2008.

[6] J. Rugai, "A REview Digital Addiction: A Call for Safety Education," Journal of Education and e-Learning Research, vol. 3, no. Digital Addiction, pp. 17-22, 2016.

[7] J. Rugai, "A Review of digital Addiction: A Call for Safety Education," Journal of Education and e-Learning Research, vol. 3, no. Digital Addictioan, p. 22, 2016

[8] K. s. Young, "Internet Addoiction: The Emergence of a New Clinical Disorder," Cyberpsychol, vol. 1, no. Internet Addioction, pp. 237-244, 2009.

[9] Yen JY, Family Factors ofInternet Addiction and Substance, vol. 10323 , Harvard: Harvard University Press, 2007, p. 9.

[10] Hadisubrata, Mengembnagkan Kepribadian Anak Balita, Jakarta: Gunung Mulia, 2017.

[11] A. Inkless, Becoming Modern: Individual Change in Six Developing Countries, Massachusetts: Harvard University Press, 2009

[12] Hadisubrata, Mengembangkan Kepribadian Anak Balita, jakarta: Gunung Mulia, 2017.

[13] E. Hurlock, Perkembangan Anak, Jakarta: Airlangga, 2013

[14] P. Hauck, Mendidik Anak yang Berhasil, Jakarta, 2015.

[15] C. S. T. Wu, "Parenting approaches, Family Functionality, and Digita Addiction among Hong Kong Adolescents," Wednesday June 2015. [Online]. Available: bmcpediatr.biomedcentral.com. [Accessed Wednesday June 2017] 